\title{
Difficulty in Mathematics: Close Assistance and Self-Confidence
}

\author{
Dr. Jerald C. Moneva \\ Department of Education \\ Mandaue City Division, Cebu, Philippines \\ E-mail: monevajerald5@gmail.com \\ Angelica Faye S. Valle \\ Jagobiao National High School \\ North Road, Jagobiao Mandaue City \\ E-mail: licafaye22@gmail.com \\ Ismaelita Desabille \\ Education supervisor, Department of Education \\ E-mail: ismaelita.desabille@deped.gov.ph
}

Received: Dec. 3, 2019 Accepted: Feb. 22, 2020 Published: February 22, 2020

doi:10.5296/jse.v10i1.16460ＵRL: https://doi.org/10.5296/jse.v10i1.16460

\begin{abstract}
Self-confidence is the belief in oneself and one's abilities. It is developed when there is someone who help them and motivate them to believe themselves. Self-confidence is the positive result of self-esteem. Self-confidence can be learning and built through assistance. Assistance from someone can help students to improve their self-confidence and the insecurity to their selves will be gone. The researcher aims to assess if the close assistance can help develop the students' self-confidence and cope up their difficulty in mathematics. The researcher used descriptive-correlation using a questionnaire and composed of 20 adapted questionnaire related to the study. 243 students answer the survey questionnaire in their respective classroom and after data gathered it has been analyzed using the weighted mean and Guttmann's Lambda to determine the relationship between the close assistance and
\end{abstract}




\section{Macrothink}

Journal of Studies in Education

ISSN 2162-6952

self-confidence. The study revealed that there is a significant relationship between close assistance and self-confidence which is the p-value is lesser than the alpha which means that assistance and self-confidence is correlated with each other. The researcher concludes that with the help of close assistance students' difficulty decreases and self-confidence increases.

Keywords: Close Assistance, Mathematics, Self-Confidence, Assistance, Ability, Problem Solving 


\section{Introduction}

\subsection{Rationale}

Mathematics is important for everyone's life. Mathematics is a universal language. It involves numbers, shapes, and even money. It is one of the major subject of the curriculum and very essential for the students learning. However, many students are having difficulties in mathematics including the students of Jagobiao National High School.

Many students find it difficult to understand mathematics because they lack skills. They may also lack of interest, lack of study habits and possess the negative attitudes of students. Mathematical skills are one of the students' needs to deal with mathematical problem solving. Problem solving of the mathematics subject is really hard but having the ability to recall, memorize and think critically it is the factors of having mathematical skills that students really need. Lack of interest of the students in mathematics might push them to have failing grades in mathematics. The negative attitudes of the students towards mathematics can fail them to solve mathematical problem. Students do not have any idea what will happen to the next level of their life if they do not want to learn mathematics and always averse the mathematics subject in their life.

There is a significant relationship between the attitudes of teachers and student's attitude towards mathematics (Mensah, Okyere \& Kuranchie, 2013). Lack of intellectual abilities causes students difficulty towards mathematics (Tambychick \& Meerah, 2010).

Self-confidence is a self-perspective that has a belief of the selves and encouragement to do something. Students' confidence could be viewed base on the way they carry themselves with trust and believe. However, each student does have different levels of self-confidence that is one of the occurring issues in school. Thus, this issue does have lot of causes and possible solutions. Students must be given assistance towards this certain issue to cope up, but there is no assurance if assistance could truly help students in boosting their self-confidence.

From above all the discussion, it was observed that there are many factors that can cause students difficulty in mathematics such as the lack of skills, interest, problem solving, study habits, negative attitude of students towards mathematics and the relationship of students and their teacher attitude towards teaching. Hence, the main goal of the research is to assess whether the difficulty in mathematics of students can be resolve by developing the confidence of students through assistance by someone who knows mathematics.

\subsection{Theoretical Background}

The study is anchored on the two theories which are the Howard Gardner's Multiple Intelligence theory and Self-Efficacy theory of Albert Bandura.

Gardner proposed eight areas of intelligence in multiple intelligence theory including the linguistic intelligence, mathematical-logical intelligence, spatial intelligence, musical intelligence, kinesthetic intelligence, and lastly the naturalist intelligence (Gardner, 2010).

The study is supported from the logical- mathematical intelligence of Gardner's Multiple 


\section{MlMacrothink}

Intelligence Theory. Logical-mathematical intelligence involves problem solving and mathematical equations, a person who possess this skill has the ability to think for themselves and balance truth.

The study is also supported from the Self-efficacy theory of Albert Bandura in 1994. Self-efficacy belief is determined how people feel, think, motivate \& believe themselves. Self-efficacy beliefs have four major processes involves cognitive, motivation, affective and selection processes. On having a strong sense of self-efficacy can enhance the accomplishment and personal well-being in many ways. The four major processes which are the cognitive, motivation, affective and selection processes can help to perceived self-efficacy as capabilities to produce designative levels of performance that influence over events that affect lives. The effects of self-efficacy on cognitive processes to take a variety of forms. It requires a strong sense of efficacy to remain task oriented in a situational demand, failures and setbacks that have significant repercussions. Self-efficacy plays a key role in the self-regulation of motivation where as people motivate themselves and guide their actions anticipatorily by the exercise of forethought. One of the four major processes of self-efficacy is affective processes where people beliefs in their coping capabilities affect how much stress and depression they experience in threating in difficult situation, as well as their level of motivation. Perceived self-efficacy to control thought processes is a key factor in regulating thought produce stress and depression. The self process has centered on efficacy activated processes that enable people to create beneficial environments and to exercise some control over those the encounter (Bandura, 1994).

In other words, the four major processes where the cognitive, motivation, affective, and selection process is part of the self-efficacy because it helps to determined how people feel, think, motivate, and believe themselves. And also it approaches a capability in dealing difficult tasks as challenges to be mastered rather than as threats to be avoided.

To further discuss, the two theories are connected to each other logical-mathematical and self-efficacy with these two theories students can enhance self-confidence cope up with their difficulty in mathematics.

\subsection{Statement of Purpose}

The study intends to assess the relationship between difficulties in mathematics: assistance and self-confidence.

Specifically, the study seek to answer the following sub problems:

1. To what extent does close assistance can help students towards their difficulty in mathematics?

2. What is the level of students' self-confidence?

3. Is there an association between the assistance and students' self-confidence towards their difficulty in mathematics?

\subsection{Significance of the Study}




\section{Mll Macrothink}

The generalization of this study would be a great contribution to the knowledge of the students and the result will give benefit specifically to the following.

Students will benefit from this study, so they may be guided in their capacity in solving math problem and gain more ideas about the different types of factors that can affect their mathematical skills and to know where they should change their behavior towards learning math subject and to know the reason why students are having a hard time with mathematics.

Teachers will benefit from this study because the data of this will give on assistance to the teachers in identifying and determining the factors of students' difficulty in mathematics. This will help the teachers to improve their students' mathematical thinking skills. This will also help to improve teacher's pedagogical techniques and use these as tools to address the student's difficulty in mathematics.

Parents will also benefit from this study because they will be able to understand the factors and obtain generic ideas on the factors that affect their children's difficulty in mathematics. With these factors, parents will be able to understand and decide an action that will help enhance the students' critical thinking abilities.

Community will also benefit from this study because the community may gain awareness as to what measures and considerations are proper to organize the teachers, parents and students on helping each other towards their difficulty in mathematics. This may also inform others about the value or worth of mathematics in the society.

Researcher will also benefit from the study as their basis to know more about strategy of difficulties in mathematics and it will guide them to add some unique concepts that related on this study.

Future researcher will also benefit from the study in such way that this study will serve as a great source of concept and ideas. Future researcher can also utilize this as their reference if they are doing parallel study as this.

\subsection{Definition of Term}

In order for the readers to fully understand the research. The researcher gives the meaning about the following terminologies.

Close Assistance someone who helps the students by his/her difficulty in mathematics.

Self-confidence the students' confidence in answering math correctly.

\section{Review of Related Literature and Studies}

This chapter consists of different review of related literature of studies to support the study Difficulty in mathematics: Close Assistance and Self-confidence.

Communication of teacher and students by face to face is an effective way to help students in analyzing mathematics topic (Wang, Du \& Liu, 2009). Creating a professional relationship and cooperation between teachers and students helps enhances students' learnings and easily conquer their difficulties (Žakelja, 2014). Strategic tutoring can enhance and develop the 
academic performance of the students. Students may improve their performance in quizzes and test from failing to above average (Hock, Pulvers, Deshler. \& Schumaker, 2001). Students should seek a unique strategy in learning in order for them to study, organize, and rehearse on their own. Students should regulate and check their selves so that they can interact and learn on their own by getting assistance from others (Newman, 2002). Student's learnings in Mathematics was found to enhance by remediation (Bahr, 2008). It is suggested to the study that professional development is needed, like orienting tutors or instructors to a new strategy, in helping the students' in learning and is found to be effective and beneficial (Perin, 2004). One assistance that this study showed are instructional situations wherein teachers translates problem scenarios because this helps students to better understand mathematics (Bosse, Adu-Gyamfe \& Cheetham, n.d). This study provided an instructional process for students' interaction. These instructional processes may show how it affects to students' problem in mathematics (Butter, Beckingham \& Lauscher, 2005). The study believes that involvement of the parents to the mathematics homework of the students have an effect to their academic achievement (Sullivan, Chen \& Fish, 2014). The study suggested that students' who have difficulties in mathematics should adopt approaches to mathematics education and value the learners' mathematical experiences (Scherer, Beswick, Healy \& Opitz, 2017). The students' difficulty in math can be avoided through intervention and continues training programs and can be implemented by the help of teachers and school administrators (Mundia, 2012). Personal Intervention is somehow a good teaching strategies for an effective instruction for the students' (Dole, n.d). Another useful assistance is helping students learn through the use of technology where students will log in into a website and an ETeacher will be there to help them. With this, mathematics may be easier (Schiaffino, Garcia \& Amandi, 2008). Also with the use of ICT's positively impacts on the difficulties towards mathematics and improves self-confidence (Adam \&Tattnall, 2010). Computer manipulatives is useful and can help widen the students' concrete knowledge especially in teaching mathematics and learning (Samara and Clements, n.d).

Self-confidence is prominent predictor of future growth among students (Hannula, Maijala \& Pehkonen, 2004). A student's academic achievement depends on their level of self-confidence. (Virma \& Kumari, 2016). Self-confidence can boost the students' minds in decision-making and can wipe away the anxiety and nervousness a student feels, therefore the higher the self-confidence the lesser the anxiety. (Das, Hadler \& Baraigya, 2014). High self-confidence into mental attitude are more creative than low self-confidence (Chen, Yang, Chen, Feng \& Guo, 2017). The academic achievement has a significant relationship to the level of self-confidence of the adolescent (Tripathy \& Srivasta, 2012). The higher the students' self-confidence the higher they gain scores in their oral. There is a significant relationship between general self-confidence and achievement in oral performance. In addition, elevating students' overall self-confidence through language learners is one way to elaborate their mastery in oral (Al-Hebaish, 2012). People's social relations could be effectively manage by having better social self-confidence (Greenacre, Tung \& Chapman, 2014). Enhancing and guiding students' personal confidence is an effective way to correct their negative attitude (Wang, Du \& Liu, 2009). A person who possess positive attitude such as having selfconfidence influences their peers and other people to be confident as well. Having 
self-confidence doesn't only come naturally because it can be learned and it is also a way for a person to be successful (Johnson, 2010). Students that are confident in having good results in mathematics may also have a mindset of mathematics difficulty (Waini, Hamzah, Said, Miswa, Zainal \& Ahmad, 2014). There is no significant effect between students' self-confidence and students' achievement. Students' age level and students' class level are factors that can affect students' self-confidence and academic achievement (Kurhentanti \& Santosa, 2018).

Mathematics achievement and enhancement of understanding and self-confidence could be found in cooperative learning (Zakaria, Solfitri, Daud \& Zainal-Abidin, 2013, Khun-Inkeeree, Omar-Fauzee \& Othman, 2017). Collaborative learning model helps students' mold and improve its self-confidence (Nurhayati, Rosmaiyadi \& Buyung, 2017).

Every individual must acquire confidence and self-assessment and by doing this, social soft skill should be followed to enhance performance, a person who have self-confidence will have the chance to discover more abilities and efficiency in doing something (Ratnasari \& Andriansyah, 2014).

\section{Research Methodology}

This chapter consists, design, locale, respondent, instrument, data gathering, analysis and statistical treatment of the research.

\subsection{Design}

The researcher used a quantitative approach-descriptive correlation to determine the significant relationship between the two variables that is conducted in the research questionnaire to gather the data that is needed in this study.

\subsection{Locale}

The research was conducted at Jagobiao National High School where able to build up 2 consecutive building that with different floors: (1) 3 floors with 6 classrooms (2) 4 floors with 8 classrooms for the Senior High School Department. The School also offers Academic tracks including Accountancy and Business Management (ABM), General Academic Strand (GAS), Humanities and Social Sciences (HUMSS), Science, Technological, Engineering, and Mathematics (STEM), and also Technical and Vocational Livelihood-Drafting (TVL-Drafting).

\subsection{Respondents}

The Senior High School Students of Jagobiao National High School, specifically of 243 students are qualified to answer the survey including the Accountancy and Business Management (ABM), General Academic Strand (GAS), Humanities and Social Sciences (HUMSS), Science, Technological, Engineering, and Mathematics (STEM), and also Technical and Vocational Livelihood-Drafting (TVL-Drafting) students.

\subsection{Instrument}




\section{Mll Macrothink}

Journal of Studies in Education

ISSN 2162-6952 2020, Vol. 10, No. 1

The tool used in this study is a Likert scale questionnaire. The researcher adapted two survey questionnaires. The first questionnaire is about the level of students' self-confidence in learning Mathematics that consists of ten questions. The second questionnaire is about the level of attitude of the students towards close assistance in learning mathematics. These questions are answerable from numbers 1-4 that stands for (1) strongly agree (2) agree (3) disagree (4) strongly disagree.

\subsection{Data Gathering}

The researcher formulated a transmittal letter to ask permission from the principal and from the teachers. The researcher adapted two survey questionnaires in Likert scale and the survey will be conducted every 11:30 - 12:30 in the afternoon. The researcher goes room to room to personally distribute the survey questionnaire to the respondent. Afterwards, the data was then collected after the respondents answered and all the results were tabulated and analyze by the researcher.

\subsection{Statistical treatment}

The data gathered from the questionnaire are tabulated for analysis and interpretation is subjected to the following statistical tool. Weighted mean a statistical tool use to add the responses of the respondents and compute for the average mean. Lambda it is use to determine the relationship between independent and dependent variable.

\section{Presentation, Analysis and Interpretation of Data}

This chapter presents and shows the data gathered, it shows the analysis and interpretation of data using weighted mean and Guttmann's lambda.

Table 1. Level of attitudes towards Close Assistance

\begin{tabular}{lll}
\hline Indicators & WM & Interpretation \\
\hline $\begin{array}{l}\text { 1. It's easy for me to understand the lesson when explained by } \\
\text { someone I know. }\end{array}$ & 2.18 & Disagree \\
2. I can solve problem when my teacher gives me more time. & 2.11 & Disagree \\
3. Watching step by step tutorials helps me in getting better. & 2.11 & Disagree \\
4. I need to slowly learn the equation step by step given by our & 2.24 & Disagree \\
teacher. & & \\
5. It's hard for me to understand the lesson when no one guides me. & 2.39 & Disagree \\
6. I need more time to understand the lesson. & 2.45 & Disagree \\
7 .I need a tutor for me to understand the lesson. & 2.47 & Disagree \\
8. I understand the lesson when the teacher explained the lesson & 2.08 & Disagree \\
clearly. & & \\
9. I can easily solve problems without any distraction. & 2.53 & Agree \\
10. I was able to find mathematics easy with the help of others. & 2.55 & Agree \\
\hline Overall weighted Mean & $\mathbf{2 . 3 1}$ & Disagree \\
\hline
\end{tabular}

Scale: $1-1.75=$ Strongly Disagree, 1.76-2.25=Disagree, 2.51-3.25=Agree, 3.26-4=strongly agree 


\section{Mll Macrothink}

The table above shows that the overall weighted mean is 2.31 and labelled as disagree. The statement "I was able to find mathematics easy with the help of others" is an indicator that has the highest weighted mean of 2.55. It signifies that in order to learn mathematics easily, there is a need for an accompaniment. In addition, Teachers support the students learning is very effective and positive teaching practices to the student's competency (Newman, 2002). It is followed by the statement "I can easily solve problems without any distraction" with a weighted mean of 2.53 and is labelled as agree. It implies that it is easy for students to solve a math problem if there are no disturbances. Then the statement "I need a tutor for me to understand the lesson" followed with a weighted mean of 2.47 and is labelled as disagree. It means that students can learn math on their own without the help of a tutor. The statements "I can solve problem when my teacher gives me more time" and "I need to slowly learn the equation step by step given by our teacher" are labelled as disagree and both are having equal weighted mean of 2.11. It signifies that the students can easily solve math problems in a given period of time and that they can learn math without the teachers giving them the steps. The statement "I understand the lesson when the teacher explained the lesson clearly" has the least weighted mean of 2.08 and is labeled as disagree. It implies that the students can't easily understand the lesson though the teachers explained it clearly. The improvement of teaching practices and overcoming the difficulties in mathematics was due to the contribution of learning difficulties in mathematics Model (Zakelja, 2014). Strategic tutoring is an effective way of improving the academic performance of the students and has a positive effect on students' test scores (Hock, Pulvers, Deshler \& Schumaker, 2011). The table shows above and has overall weighted mean of 2.48 labelled as disagree this means that students' don't need an assistance of someone to answer and learn mathematics subject.

Table 2. Close Assistance

\begin{tabular}{lll}
\hline Category & Frequency & Percentage \\
\hline Very Low Assistance & 1 & 0.4 \\
Low Assistance & 118 & 48.6 \\
Average Assistance & 107 & 44 \\
High Assistance & 17 & 7 \\
Very High Assistance & 0 & 0 \\
\hline Total & $\mathbf{2 4 3}$ & $\mathbf{1 0 0}$ \\
\hline
\end{tabular}

Scale: 1-10=Very Low Assistance, 11-20=Low Assistance, 21-30=Average Assistance, 31-40=High Assistance, 41-50=Very High Assistance.

The table above shows that the highest number of respondents who scored 11-20 with the percentage of $48.6 \%$ interpreted as Low assistance. The second greatest number of respondents who scored 21-30 with the percentage of 44\% labelled as Average assistance and lastly the lowest number of respondents who scored 31-40 with the percentage of $7 \%$ interpreted as High assistance.

The table above showed that students got low assistance from someone. Therefore, students got assistance but not the average assistance of someone that students really need. Students 
who don't want remedial classes but assistance in learning can enhance their reading, writing and math skills (Perin, 2014). Children will believe that they can exert positive influence on their grades and academic outcome with the help of parental provision structure (Sullivan, Chen \& Fish, 2014). It is also a vital factor for students to learn the act of seeking advices to their peers that help students in reaching success (Newman, 2002).

Table 3. Level of Self-confidence

\begin{tabular}{|c|c|c|}
\hline Indicators & WM & Interpretation \\
\hline 1. Mathematics does not scare me at all. & 3.36 & Strongly agree \\
\hline 2. I can solve problems by just looking at the formula. & 3.42 & strongly agree \\
\hline 3. I can solve problems through different strategies. & 2.76 & Agree \\
\hline $\begin{array}{l}\text { 4. I am comfortable expressing my own ideas on how to } \\
\text { look solutions to a difficult problem in math. }\end{array}$ & 2.52 & Agree \\
\hline 5. I am comfortable answering questions in math class. & 2.48 & Disagree \\
\hline $\begin{array}{l}\text { 6. I get great deal of satisfaction out of solving a } \\
\text { mathematics problem. }\end{array}$ & 2.68 & Agree \\
\hline $\begin{array}{l}\text { 7. I am able to solve mathematical problem without too } \\
\text { much difficulty. }\end{array}$ & 3.00 & Agree \\
\hline $\begin{array}{l}\text { 8. Studying at home helps me improve my problem } \\
\text { solving skills. }\end{array}$ & 2.48 & Disagree \\
\hline 9. I can easily solve problems without any distraction. & 2.92 & Agree \\
\hline 10. Mathematics excites me. & 2.84 & Agree \\
\hline Overall weighted Mean & 2.85 & Agree \\
\hline
\end{tabular}

Scale: 1-1.75=Strongly Disagree, 1.76-2.25=Disagree, 2.51-3.25=Agree, 3.26-4=strongly agree

The table above shows that the overall weighted mean is 2.85 and labelled as agree. The statement "I can solve problems by just looking at the formula" is an indicator that has the highest weighted mean of 3.42 which means that students can answer math problem by just directly looking at the formula. It is followed by the statement " Mathematics does not scare me at all" with 3.36 weighted mean and labelled as agree. It signifies that students have self-confidence and does not scared in solving math problems. The statement "I am able to solve mathematical problem without too much difficulty." with the weighted mean of 3.00 and labelled as agree. It signifies that students can answer mathematics without any difficulty. The statement "I am comfortable expressing my own ideas on how to look solutions to a difficult problem in math" with a weighted mean of 2.52 and labelled as agree. Which means that they are comfortable in expressing their own ideas and in finding solutions for math problems. The statements "I am comfortable answering questions in math class." and "Studying at home helps me improve my problem solving skills" are labelled as disagree and both are having equal weighted mean of 2.48. This means that they are not comfortable in answering math problems and staying at home cannot improve their difficulty and students are not comfortable in answering questions. 


\section{NI Macrothink}

In general, it has been claimed above that students have believe in themselves or self-confidence and it is significant to their mathematics achievement. Students' confidence and mathematics achievement are significant because confidence is belonging to the attitudes of students (Mohd, Mahmood \& Ismail, 2011). Students' who have more self-confidence obtain a highest score (Al-Hebaish, 2012). Insecurity and self-confidence can be affected by the academic achievement of a student (Tripathy and Srivastava, n.d).

Table 4. Self-confidence

\begin{tabular}{lll}
\hline Category & Frequency & Percentage \\
\hline Not Confident & 0 & 0 \\
Slightly Confident & 18 & 7.4 \\
Fairly Confident & 154 & 63.4 \\
Moderately Confident & 71 & 29.2 \\
Completely Confident & 0 & 0 \\
\hline Total & $\mathbf{2 4 3}$ & $\mathbf{1 0 0}$ \\
\hline
\end{tabular}

Scale: $\quad 1-10=$ Not Confident, $11-20=$ Slightly Confident, 21-30=Fairly Confident, 31-40=Moderately Confident, 41-50=Completely Confident

The table above shows that the highest number of respondents who scored 21-30 with the percentage of $63.4 \%$ interpreted as fairly confident. The second greatest number of respondents who scored 31-40 with the percentage of $29.2 \%$ interpreted as moderately confident and lastly the lowest number of respondents who scored 11-20 with the percentage of $7.41 \%$ interpreted as slightly confident.

The table above implies that most of the students are fairly confident in facing mathematics subject. Therefore, the Senior High School students of Jagobiao National High School have self-confidence but their level of self-confidence is low. Having positive outlook and optimistic mindset help students develop their capacity of achieving success by enhancing their actions and thoughts (Chen, Yang, Feng \& Guo, 2017). Acquiring a positive attitude such as self-confidence enable students to cope in dealing with challenges in their studies such as mathematics (Waini, Hamzah, Said, Miswan, Sainal \& Ahmad, 2014). Being successful comes with confidence and to achieve such success; guidance is needed for students to facilitate their capabilities that would make them successful (Virma \& Kumari, 2016). 
Table 5. Close Assistance and Self-confidence

Nominal by Nominal

\begin{tabular}{|c|c|c|c|c|}
\hline $\begin{array}{l}\text { Lambda } \\
\text { Symmetric } \\
\text { Close Assistance } \\
\text { Self-confidence }\end{array}$ & Value & Asymp. Std. Error ${ }^{\mathrm{a}}$ & Approx. $\mathrm{T}^{\mathrm{b}}$ & Approx. Sig. \\
\hline \multirow{3}{*}{$\begin{array}{l}\text { Symmetric } \\
\text { Close Assistance } \\
\text { Self-confidence }\end{array}$} & .145 & .029 & 4.850 & .000 \\
\hline & .115 & .039 & 4.857 & .004 \\
\hline & .173 & .034 & 2.804 & .000 \\
\hline
\end{tabular}

There is a significant association between the two variables the close assistance and self-confidence because the p-value (.000) is lesser than the significant alpha (.05). A concrete and positive relationship between close assistance and self-confidence revealed $(\mathrm{p}=.000>.05)$. This means that close assistance correlate with each other. Close assistance has $11.5 \%$ that have tendency to affect the students' self-confidence. Self-confidence has $17.3 \%$ to affect the close assistance.

It has been showed above that close assistance and students' self-confidence has a significant relationship to each other and also with the help of close assistance students can enhance self-confidence. Students' parents should be educated to help their children's achievement in mathematics by creating strategies and methods that are applicable at home (Sullivan, Chen \& Fish, 2014). Communication to their teachers and self-confidence of the students is an effective way to reduce difficulty (Wang, Du \& Liu. 2009). Collaborative learning model helps the improvement of the students learning mathematics and confidence (Nurhayati, Rosmaiyadi \& Buyung, 2017).

\section{Summary of Findings, Conclusion and Recommendations}

This chapter presents the findings, conclusions and recommendations and limitations of the study.

\subsection{Findings}

In this study. The researcher found out that students' does not need and assistance of someone to learn mathematics. It is also found out that most of the students disagreed that they can learn mathematics or answer with the help of others.

The study revealed that students' self-confidence can help students' difficulty in mathematics. With the help of the overall weighted mean and labelled as agree that students' have self-confidence in answering mathematics problems. Therefore, students' self-confidence can be one way to resolve students' difficulty.

The result of this study between the two variables does have positive relationship. Mathematics cannot be difficult unless students' understanding is good with self-confidence. 


\section{Mll Macrothink}

With the help of the teachers and parents, students can easily get the lesson and answer it without difficulty in mathematics. Therefore, the close assistance and self-confidence are correlated to each other.

\subsection{Conclusion}

Students may find that mathematics is a hard subject. Students difficulty in mathematics can be resolve with the help of close assistance in developing students self-confidence. Both variables identified close assistance and self-confidence have positive relationship to each other. With close assistance students can face their difficulty and can develop self-confidence. Meanwhile, students have to trust and believe that they can tackle mathematical problem and shall overcome their fear and inhibitions. It is also consider that self-confidence also have a big part of students in order for them to manifest their being timid before. In this case students are able to showcase what's inside of them so that they will know that they're all have potentials in mathematics. Which could be a mean in coping difficulty in mathematics. It helps students to do better. Apparently, self-confidence is one of the essential quality that every student should posses because it helps them lessen their difficulty in mathematics. It implies that with the help of close assistance, student's difficulty in mathematics decreases and level of self-confidence increases.

\subsection{Recommendation}

Based on the findings and conclusion, the following are recommended:

1. Students need assistance of other people in order for them to fully understand math.

2. Parents should motivate their child to study more, parents also have their learning style of their children in order them to help and cope up with their children's difficulty.

3. Students should have self-confidence and willingness to learn mathematics, having confidence can reduce their difficulty, and also helps to improve their mathematical ability.

\section{References}

Adam T., \& Tattnall (2010). Use of ICT to assist students with learning difficulties: an actor-Network analysis. IFIP International Federation for Information Processing AICT 324, 1-11. https://doi.org/10.1007/978-3-642-15378-5_1

Al-Hebaish S. (2012). The correlation between general self-confidence and academic achievement in the oral presentation course. Theory and Practice in Language Studies, 2(1), 60-65. https://doi.org/10.4304/tpls.2.1.60-65

Bahr P. (2008). Does mathematics remediation work? A comparative analysis of academic attainment among company college students. Res High Educ, 49, 420-450. https://doi.org/10.1007/s11162-008-9089-4

Bosse M., Adu-Gyamfe K., \& Cheetham M. (n.d). Assessing the difficulty of mathematical translations: Synthesizing the literature and novel findings. International Electronic Journal of Mathematics Education-IEJME, 6(3). 
Butler D., Beckingham B., \& Lauscher H. (2005). Promoting strategic learning by eighth-grade students struggling in mathematics: a report of three case studies. Learning $\begin{array}{lllll}\text { Disabilities } \quad \text { Research } \quad \text { \& } & \text { 156-174. }\end{array}$ https://doi.org/10.1111/j.1540-5826.2005.00130.x

Chen R., Yang Y., Chen L., Feng C., \& Guo G. (2017). A study of the correlation between self-confidence and professional achievement of designers. MATEC web of Conferences 119, 01024.

Das S., Halder U., \& Baraigya S. (2014). A study on self-confidence vs. mathematics anxiety in rural teenager students. International Journal of Informative \& Futuristic Research, 1(9), $1-4$.

Dole S. (n.d). Applying psychological theory to helping students overcome learned difficulties in mathematics: an alternative approach to intervention. SAGE Social Science, 24(1), 95-114. https://doi.org/10.1177/0143034303024001582

Greenacre L., Tung M. \& Chapman T. (2014). Self-confidence and the ability to influence. Academy of Marketing Studies Journal, 18(2), 169-180.

Hannula M., Maijala H., \& Pehkonen (n.d). Development of understanding and self-confidence in mathematics; grades 5-8. Group for the Psychology of Mathematics Education, 3,17-24.

Hock M., Pulvers K., Deschler D., \& Schumaker I. (2011). The effect of an after-school tutoring program on the academic performance of at-risk students and student with LD. Remedial and special education, 2(3),172-180. https://doi.org/10.1177/074193250102200305

Johnson E. (2010). Improving positive self-confidence. Journal of School Social Work, 6(11), $1-32$.

Khun-Inkeeree H., Omar-Fauzee M. \& Othman M. (2017). The effects of students confidence level toward mathematics performance among southern Thailand primary school children. International Journal Of Academic Research in Progressive Education and Development, 6(2),1-10. https://doi.org/10.6007/IJARPED/v6-i2/2934

Kunhertanti K., \& Santosa R. (2018). The influence of students' self-confidence on mathematics learning achievement. IOP Conf. Series: Journal of Physics: Cond. Series 1097,012126. https://doi.org/10.1088/1742-6596/1097/1/012126

Mensah, J.k., Okyere M., \& Kuranchie., A. (2013). Student attitude towards mathematics and performance: does the teacher attitude matter? Journal of Education and Practice, 4(3).

Mohd N., Mahmood T., \& Ismail M., (2011). Factors that influence students in Mathematics achievement. International Journal of Academic Research, 3, 49-54.

Mundia L. (2012). The assessment of math learning difficulties in a primary grade-4 child with high support needs: mixed methods approach. International Electronic Journal of Elementary Education, 4(2), 347-366. 


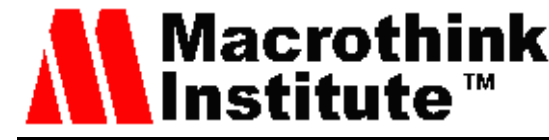

Journal of Studies in Education ISSN 2162-6952 2020, Vol. 10, No. 1

Newman R. (2002). How self-regulated learners cope with academic difficulty: the role of adaptive help seeking. Theory into practice, 41(2), 132-138. https://doi.org/10.1207/s15430421tip4102_10

Nurhayati, Rosmaiyadi, \& Buyung. (2017). Efforts to improve students self-confidence using collaborative learning model. Journal Pendidikan Matematika Indonesia, 2(2), 57-62. https://doi.org/10.26737/jpmi.v2i2.223

O'Sullivan R., Chen Y., \& Fish C. (2014). Parental mathematics homework involvement of low-income families with middle school students. School Community Journal, 24(2), 165-188, https://psycnet.apa.org/record/2014-56242-008

Perin D. (2004). Remediation beyond development education: the use of learning assistance centers to increase academic preparedness in community colleges. Community College Journal of Research and Practice, 28,559-582. https://doi.org/10.1080/10668920490467224

Ratnasari S., \& SalimAndriansyah (2014). Effect of self confident and self assessment for performance with social skill as moderating variables. IOSR journal of Business and management (IOSR-JBM), 16(11),43-47.

Sanchal A., \& Sharma S. (2017). Students' attitudes towards learning mathematics: impact of teaching in a sporting context. Teachers and Curriculum, 17(1), 89-99. https://doi.org/10.15663/tandc.v17i1.151

Samara J., \& Clements D. (2009). Concrete computer manipulatives in mathematics education. Society for Research in Child Development, 3(3), 145-150. https://doi.org/10.1111/j.1750-8606.2009.00095.x

Scherer P., Beswick K., Delbois L., Healy L., \& Opitz E. (2017). Assistance of students with mathematical learning disabilities-how can research support practice-a summary. Proceedings of the $13^{\text {th }}$ International Congress on Mathematical Education, ICME-13. https://doi.org/10.1007/978-3-319-62597-3_16

Schiaffino S., Garcia P., \& Amandi A. (2008). ETeacher: Providing personalized assistance to e-learning students. Computers and Education, 51,b1744-1754. https://doi.org/10.1016/j.compedu.2008.05.008

Tambychick T., \& Mohd Meerah T. (2010). Students' difficult in mathematics problem-solving: what do they say? Procedia Social and Behavioral Sciences, 8, 142-151. https://doi.org/10.1016/j.sbspro.2010.12.020

Tripathy M., \& Srivasta K. (n.d) To study the effect of academic achievement on the level of self-confidence. International Journal of Yoga and Allied Sciences, 1(1),33-45.

Verma R. \& Kumari S. (2016). Effect of self-confidence on academic achievement of children at elementary stage. Parepix-Indian Journal of Research, 5(1),181-183.

Waini I., Hamzah K., Said R., Miswan N., Sainal N., \& Ahmad A. (2014). Self-confidence in mathematics: a case study on engineering technology students in FTK,UTeM. International 


\section{Macrothink}

Journal of Studies in Education

ISSN 2162-6952 2020, Vol. 10, No. 1

Journal For Innovation Education Research, 2(11), 1-4, https://www.ijier.net/index.php/ijier/article/view/262

Wang G., Du H, \& Liu Y (2009). Case study on improving high school students with learning difficulties in mathematics. Journal of Mathematics Education, 2(2),122-133.

Zakaria E., Solfitri T., Daud Y., \& Abidin Z. (2013). Effect of cooperative learning on secondary school students' mathematics achievement. Scientific Research, 4(2), 98-100. https://doi.org/10.4236/ce.2013.42014

Žakelja A. (2014) Support to pupils with learning difficulties in mathematics. Procedia -Social and Behavioral Sciences, 159,506-511. https://doi.org/10.1016/j.sbspro.2014.12.414

\section{Appendix}

Appendix 1. Level of attitude towards Close Assistance

Directions: This questionnaire is about how students react in learning mathematics. Answer the Following questions honestly. Put a check mark on the statement that corresponds to your answer using the following scales: (4) strongly disagree, (3) disagree, (2) agree, (1) strongly agree

\begin{tabular}{|c|c|c|c|c|}
\hline Level of attitude towards Close Assistance & 4 & 3 & 2 & 1 \\
\hline 1. It's easy for me to understand the lesson when explained by someone I know. & & & & \\
\hline 2. I can solve problem when my teacher gives me more time. & & & & \\
\hline 3. Watching step by step tutorials helps me in getting better. & & & & \\
\hline 4. I need to slowly learn the equation step by step given by our teacher. & & & & \\
\hline 5. It's hard for me to understand the lesson when no one guides me. & & & & \\
\hline 6. I need more time to understand the lesson. & & & & \\
\hline 7. I need a tutor to understand the lesson. & & & & \\
\hline 8. I understand the lesson when the teacher explained the lesson clearly. & & & & \\
\hline 9. I can easily solve problems without any distraction. & & & & \\
\hline 10. I was able to find mathematics easy with the help of others. & & & & \\
\hline
\end{tabular}




\section{Appendix 2. Level of Self-confidence}

Directions: This questionnaire is about how students react in learning mathematics. Answer the Following questions honestly. Put a check mark on the statement that corresponds to your answer using the following scales: (4) strongly disagree, (3) disagree, (2) agree, (1) strongly agree

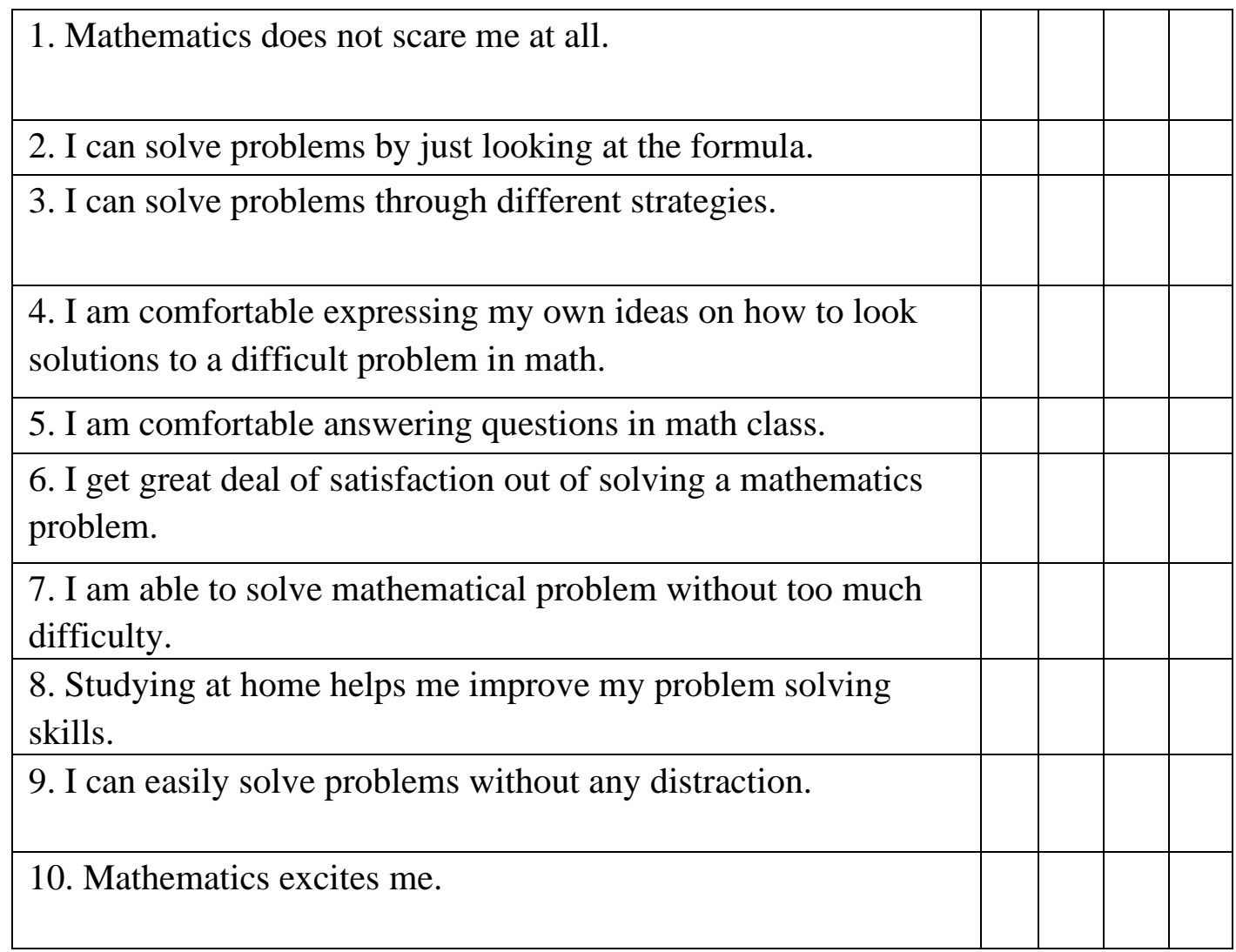

